\title{
Analysis of DICER1 in familial and sporadic cases of Transposition of the Great Arteries
}

\section{Nelly Sabbaghian ${ }^{1}$, M.Cristina Digilio² ${ }^{2}$ Gillian M Blue ${ }^{3}$, David S.Winlaw ${ }^{3}$, William D Foulkes M $^{1,4}$}

${ }^{1}$ Lady Davis Institute, Segal Cancer Centre, Jewish General Hospital, Montreal, Quebec, Canada

${ }^{2}$ Department of Medical Genetics, Bambino Gesù Pediatric Hospital, Rome, Italy

${ }^{3}$ Heart Centre for Children, The Children's Hospital at Westmead, Westmead, New South Wales 2145, and University of Sydney, Australia

${ }^{4}$ Program in Cancer Genetics, Departments of Oncology and Human Genetics, McGill University,

Montreal, Quebec, Canada

Nelly Sabbaghian: nelly.sabbaghian@mail.mcgill.ca

M.Cristina Digilio: mcristina.digilio@opbg.net

Gillian M Blue: gillian.blue@ health.nsw.gov.au

David S.Winlaw: david.winlaw@ health.nsw.gov.au

Corresponding author is Dr William D Foulkes: william.foulkes@ mcgill.ca 
Abstract 148 words

Background: DICERI plays a major role in development and in generating mature microRNAs that are important in gene expression. We screened for DICER1 mutations in a family with DICER1 syndrome and we discovered a pathogenic mutation in a child with transposition of the great arteries (TGA). In view of a report linking DICERl knock-out in murine cardiomyocytes to cardiac outflow defects, we

6 investigated the involvement of DICER1 in TGA.

7 Findings: We screened 129 germline DNA samples from children with either sporadic or familial forms

8 of TGA for DICERI mutations using a Fluidigm access array, followed by next-generation sequencing.

9 We identified 16 previously reported variants (5 synonymous, 6 intronic, and 5 missense) and 2 novel

10 variants (1 intronic and 1 missense). We did not find any apparent pathological mutation in our cohort.

11 Conclusion: Here we report that DICER1 mutations do not appear to play a major role in TGA. Keywords TGA, DICER1

16 DICER1 is an endoribonuclease that plays an essential role in modulating the expression of genes by 17 producing mature microRNAs (miRNA), which are small, single stranded RNA molecules that bind to and thereby inhibit target mRNAs. DICERI-related diseases are referred to collectively as DICER1 syndrome and result from germline mutations in individuals with rare childhood cancers such as: pleuropulmonary blastoma, cystic nephroma, Sertoli-Leydig cell tumor, embryonal rhabdomyosarcoma

21 and other rare tumors[1] [. Several years ago, we identified a deleterious germline DICERI mutation

22 (c.2117-1G>A, in intron 13 at the junction with exon 14, predicted to result in p.Gly706Aspfs*8) in a

23 child with transposition of the great arteries (TGA), associated with a bicuspid pulmonary valve, an atrial 24 septal defect and a patent ductus arteriosus [2]]. Later, at the age of 18, he developed a solitary nodule in 
the left lobe of the thyroid gland. Two years later, he was found to have further nodules and cysts in the same lobe. Other mutation-carrying persons in the family also had phenotypes consistent with the DICER1syndrome [2]. Saxena and Tabin had reported cardiac outflow defects in mice with a conditional knock-out of Dicer in the developing murine heart [3]. These two observations prompted us to screen for DICER1 mutations in familial and sporadic cases with TGA. TGA is a cyanotic congenital heart defect (CHD) characterized by ventriculo-arterial discordance and represents 5 to $7 \%$ of CHD [4]. It is often accompanied by other structural changes that allow mixing of oxygenated and de-oxygenated blood, although there have been studies looking for the genetic causes of TGA, data so far have been inconclusive[5] .

We screened 129 germline DNA samples from children with sporadic $(n=91)$ or familial $(n=38)$ forms of TGA for DICERI mutations using a Fluidigm access array, followed by next-generation sequencing and confirmatory Sanger sequencing [6]. Eighty-two cases were from Australia and 47 were from Italy. Details of the cases studied are shown in Supplementary Table 1. All patients signed an IRB-approved consent form.

41 No DICERl variants were detected in 110 cases. Nineteen individuals had one or more variants for a total

42 of 5 synonymous, 7 intronic and 6 missense variants (Supplementary Table 2). c.307+13T >C and c.4886C $>\mathrm{T}$ are novel intronic and missense variants, respectively. c.4886C $>\mathrm{T}$ results in a protein with an amino acid change at position 1629, from serine to proline, (p.S1629L). SIFT (Sorting Intolerant from Tolerant)[7] and Polyphen 2 (Polymorphism Phenotyping-2)[8] predicted this variant to be "tolerated and benign”, respectively. Predictions for the other missense variants varied from possibly damaging to

47 benign by Polyphen 2, but all variants identified were predicted to be tolerated by SIFT (supplementary table 2). No definitively damaging mutations in DICERI were found. In particular, we did not identify any mutations predicted to result in a truncated protein. Thus far, most disease-associated germline mutations in DICERI are predicted to truncate the protein [1]. 
51 This study suggests that TGA is not caused by DICERI mutations in humans. The full spectrum of

52 phenotypes associated with DICERI mutations is still being defined, and newly-associated phenotypes

53 such as pituitary blastoma[6] and macrocephaly [9] are still emerging. As such, it is important to fully

54 explore all possible associations. Here we report that TGA does not appear to be part of the DICER1

55 syndrome. The genetics of TGA remain enigmatic [4] and it is likely that whole genome approaches in a

56 large series of cases will be required to identify causal variants and genetic modifiers.

57

\section{List of abbreviations}

59 TGA: Transposition of the great arteries; miRNA: microRNAs; CHD: congenital heart defect

60 Declarations

61 Ethics approval and consent to participate

62 All patients signed an IRB-approved consent form to participate in the study.

\section{Consent for publication}

64 Not Applicable.

\section{Availability of data and material}

66 The datasets used and/or analysed during the current study available from the corresponding author on

67 reasonable request.

\section{Competing interests}

69 The authors declare that they have no competing interests.

\section{$70 \quad$ Funding}

71 This work was funded by Alex's Lemonade Stand Foundation.

\section{Authors' contributions}

73 NS analyzed and validated the results, and wrote the manuscript. WDF wrote the manuscript with NS,

74 and oversaw the study. MCD, GMB, and DSW provided the samples. The manuscript was reviewed and 
75 edited by all authors, who commented on and approved the final version. All authors read and approved

76 the final manuscript.

\section{Acknowledgments}

78 This work was funded by Alex's Lemonade Stand Foundation. We thank Dr Catherine Choong, Perth,

79 Australia, for drawing our attention to the possible connection between TGA and DICER1, and for providing updated clinical information on the patient in question. We also thank Mr François Plourde,

81 Montreal, for his help in coordinating reception of the DNA samples, Nancy Hamel and Mona Wu,

82 Montreal, for their help in editing the manuscript.

\section{References}

1. Foulkes, W.D., J.R. Priest, and T.F. Duchaine, DICER1: mutations, microRNAs and mechanisms. Nat Rev Cancer, 2014. 14(10): p. 662-72.

2. Foulkes, W.D., et al., Extending the phenotypes associated with DICERl mutations. Hum Mutat, 2011. 32(12): p. 1381-4.

3. Saxena, A. and C.J. Tabin, miRNA-processing enzyme Dicer is necessary for cardiac outflow tract alignment and chamber septation. Proc Natl Acad Sci U S A, 2010. 107(1): p. 87-91.

4. De Luca, A., et al., Familial transposition of the great arteries caused by multiple mutations in laterality genes. Heart, 2010. 96(9): p. 673-7.

5. Muncke, N., et al., Missense mutations and gene interruption in PROSIT240, a novel TRAP240like gene, in patients with congenital heart defect (transposition of the great arteries). Circulation, 2003. 108(23): p. 2843-50.

6. de Kock, L., et al., Pituitary blastoma: a pathognomonic feature of germ-line DICERl mutations. Acta Neuropathol, 2014. 128(1): p. 111-22.

987 7g, P.C. and S. Henikoff, SIFT: Predicting amino acid changes that affect protein function. Nucleic Acids Res, 2003. 31(13): p. 3812-4. counts of independent observations. Protein Eng, 1999. 12(5): p. 387-94.

102 9. Khan, N.E., et al., Macrocephaly associated with the DICER1 syndrome. Genet Med, 2016. 
Supplementary Table 1: DICER1 screening results in 47 Italian and 82 Australian germline DNA samples with clinical information.

\begin{tabular}{|c|c|c|c|c|}
\hline Case ID & Variant & Status & Clinical Info & $\begin{array}{c}\text { Country of } \\
\text { Origin }\end{array}$ \\
\hline 1 & negative & Sporadic & Malformation of outflow tracts & Italy \\
\hline 2 & negative & Sporadic & Malformation of outflow tracts & Italy \\
\hline 3 & negative & Sporadic & Malformation of outflow tracts & Italy \\
\hline 4 & negative & Sporadic & Malformation of outflow tracts & Italy \\
\hline 5 & negative & Sporadic & Malformation of outflow tracts & Italy \\
\hline 6 & negative & Sporadic & Malformation of outflow tracts & Italy \\
\hline 7 & negative & Sporadic & Malformation of outflow tracts & Italy \\
\hline 8 & negative & Sporadic & Malformation of outflow tracts & Italy \\
\hline 9 & c.5504A>C p.Y1835S rs747510783 & Sporadic & Malformation of outflow tracts & Italy \\
\hline 10 & negative & Sporadic & Malformation of outflow tracts & Italy \\
\hline 11 & negative & Sporadic & Malformation of outflow tracts & Italy \\
\hline 12 & negative & Sporadic & Malformation of outflow tracts & Italy \\
\hline 13 & negative & Sporadic & Malformation of outflow tracts & Italy \\
\hline 14 & c.1935G>A p.P645P rs61751177 & Sporadic & Malformation of outflow tracts & Italy \\
\hline 15 & c. $278 \mathrm{G}>$ A p.G93E rs776219930 & Sporadic & Malformation of outflow tracts & Italy \\
\hline 16 & negative & Sporadic & Malformation of outflow tracts & Italy \\
\hline 17 & c.5364+18C $>$ T rs777415635 & Sporadic & Malformation of outflow tracts & Italy \\
\hline 18 & negative & Sporadic & Malformation of outflow tracts & Italy \\
\hline 19 & negative & Sporadic & Malformation of outflow tracts & Italy \\
\hline 20 & negative & Sporadic & Malformation of outflow tracts & Italy \\
\hline 21 & c. $1377-4 \mathrm{~T}>\mathrm{G}$ rs192490028 & Sporadic & Malformation of outflow tracts & Italy \\
\hline 22 & negative & Sporadic & Malformation of outflow tracts & Italy \\
\hline 23 & negative & Sporadic & Malformation of outflow tracts & Italy \\
\hline 24 & negative & Sporadic & Malformation of outflow tracts & Italy \\
\hline 25 & negative & Sporadic & Malformation of outflow tracts & Italy \\
\hline 26 & c.2718C >T p.R906R rs370692165 & Sporadic & Malformation of outflow tracts & Italy \\
\hline 27 & negative & Sporadic & Malformation of outflow tracts & Italy \\
\hline 28 & negative & Sporadic & Malformation of outflow tracts & Italy \\
\hline 29 & negative & Sporadic & Malformation of outflow tracts & Italy \\
\hline 30 & negative & Sporadic & Malformation of outflow tracts & Italy \\
\hline 31 & negative & Sporadic & Malformation of outflow tracts & Italy \\
\hline 32 & negative & Sporadic & Malformation of outflow tracts & Italy \\
\hline 33 & negative & Sporadic & Malformation of outflow tracts & Italy \\
\hline 34 & negative & Sporadic & Malformation of outflow tracts & Italy \\
\hline 35 & negative & Sporadic & Malformation of outflow tracts & Italy \\
\hline 36 & negative & Sporadic & Malformation of outflow tracts & Italy \\
\hline 37 & negative & Sporadic & Malformation of outflow tracts & Italy \\
\hline 38 & negative & Sporadic & Malformation of outflow tracts & Italy \\
\hline 39 & negative & Sporadic & Malformation of outflow tracts & Italy \\
\hline 40 & negative & Sporadic & Malformation of outflow tracts & Italy \\
\hline 41 & negative & Sporadic & Malformation of outflow tracts & Italy \\
\hline 42 & negative & Familial & Malformation of outflow tracts* & Italy \\
\hline 43 & c.1935G>A p.P645P rs61751177 & Familial & Ventricular Septal Defect* & Italy \\
\hline 44 & negative & Familial & Malformation of outflow tracts\# & Italy \\
\hline 45 & negative & Familial & Tetralogy of Fallot\# & Italy \\
\hline 46 & negative & Familial & Malformation of outflow tracts^ & Italy \\
\hline 47 & negative & Familial & Atrial Septal Defect ${ }^{\wedge}$ & Italy \\
\hline
\end{tabular}


bioRxiv preprint doi: https://doi.org/10.1101/125633; this version posted April 7, 2017. The copyright holder for this preprint (which was not certified by peer review) is the author/funder, who has granted bioRxiv a license to display the preprint in perpetuity. It is made available under aCC-BY-NC-ND 4.0 International license.

\begin{tabular}{|c|c|c|c|c|}
\hline 48 & negative & Sporadic & Malformation of outflow tracts & Australia \\
\hline 49 & c.5145C>T p.L1715L rs139500905 & Sporadic & Malformation of outflow tracts & Australia \\
\hline 50 & negative & Sporadic & Malformation of outflow tracts & Australia \\
\hline 51 & negative & Sporadic & Malformation of outflow tracts & Australia \\
\hline 52 & negative & Sporadic & Malformation of outflow tracts & Australia \\
\hline 53 & negative & Sporadic & Functional single ventricle & Australia \\
\hline 54 & negative & Sporadic & Malformation of outflow tracts & Australia \\
\hline 55 & negative & Sporadic & Malformation of outflow tracts & Australia \\
\hline 56 & negative & Sporadic & Functional single ventricle & Australia \\
\hline 57 & negative & Sporadic & Malformation of outflow tracts & Australia \\
\hline 58 & c. $574-5 \mathrm{G}>\mathrm{A}$ rs368253792 & Sporadic & Malformation of outflow tracts & Australia \\
\hline 59 & negative & Familial & Malformation of outflow tracts & Australia \\
\hline 60 & negative & Familial & Functional single ventricle & Australia \\
\hline 61 & c.1935G>A p.P645P rs61751177 & Sporadic & Malformation of outflow tracts & Australia \\
\hline 62 & c.179C > T p.T60I rs587778228 & Familial & Malformation of outflow tracts & Australia \\
\hline 63 & negative & Familial & Functional single ventricle & Australia \\
\hline 64 & negative & Sporadic & Functional single ventricle & Australia \\
\hline 65 & c. $1377-4 \mathrm{~T}>\mathrm{G}$ rs 192490028 & Sporadic & Heterotaxy & Australia \\
\hline 66 & negative & Familial & Functional single ventricle & Australia \\
\hline 67 & negative & Sporadic & Functional single ventricle & Australia \\
\hline 68 & negative & Sporadic & Functional single ventricle & Australia \\
\hline 69 & negative & Familial & Malformation of outflow tracts & Australia \\
\hline 70 & negative & Sporadic & Malformation of outflow tracts & Australia \\
\hline 71 & negative & Sporadic & Malformation of outflow tracts & Australia \\
\hline 72 & negative & Familial & Malformation of outflow tracts & Australia \\
\hline 73 & negative & Sporadic & Malformation of outflow tracts & Australia \\
\hline 74 & negative & Familial & Malformation of outflow tracts & Australia \\
\hline 75 & negative & Familial & Malformation of outflow tracts & Australia \\
\hline 76 & negative & Familial & Malformation of outflow tracts & Australia \\
\hline 77 & negative & Familial & Malformation of outflow tracts & Australia \\
\hline 78 & negative & Sporadic & Malformation of outflow tracts & Australia \\
\hline 79 & negative & Familial & Malformation of outflow tracts & Australia \\
\hline 80 & negative & Familial & Malformation of outflow tracts & Australia \\
\hline 81 & negative & Sporadic & Malformation of outflow tracts & Australia \\
\hline 82 & c. $2337 \mathrm{~A}>\mathrm{G}$ p.T779T rs747210633 & Familial & Malformation of outflow tracts & Australia \\
\hline \multirow{3}{*}{83} & c. $2040+29 \mathrm{~T}>\mathrm{C}$ rs370866625 & \multirow{3}{*}{ Familial } & \multirow{3}{*}{ Malformation of outflow tracts } & \multirow{3}{*}{ Australia } \\
\hline & c.3458G>A p.C1153Y rs762999390 & & & \\
\hline & c. $5527+19 A>G$ rs 765497219 & & & \\
\hline 84 & negative & Familial & Heterotaxy & Australia \\
\hline 85 & negative & Familial & Malformation of outflow tracts & Australia \\
\hline 86 & negative & Sporadic & Malformation of outflow tracts & Australia \\
\hline 87 & negative & Sporadic & Malformation of outflow tracts & Australia \\
\hline 88 & negative & Familial & Functional single ventricle & Australia \\
\hline 89 & negative & Sporadic & Malformation of outflow tracts & Australia \\
\hline 90 & negative & Sporadic & Malformation of outflow tracts & Australia \\
\hline 91 & $\begin{array}{c}\text { c.3093+149_3093+153delGTTTT } \\
\text { rs575610432 }\end{array}$ & Sporadic & Malformation of outflow tracts & Australia \\
\hline 92 & negative & Familial & Malformation of outflow tracts & Australia \\
\hline 93 & negative & Sporadic & Functional single ventricle & Australia \\
\hline 94 & negative & Sporadic & Malformation of outflow tracts & Australia \\
\hline 95 & c. $1935 \mathrm{G}>$ A p.P645P rs61751177 & Sporadic & Malformation of outflow tracts & Australia \\
\hline 96 & negative & Sporadic & Malformation of outflow tracts & Australia \\
\hline 97 & negative & Familial & Malformation of outflow tracts & Australia \\
\hline 98 & negative & Sporadic & Malformation of outflow tracts & Australia \\
\hline
\end{tabular}


bioRxiv preprint doi: https://doi.org/10.1101/125633; this version posted April 7, 2017. The copyright holder for this preprint (which was not certified by peer review) is the author/funder, who has granted bioRxiv a license to display the preprint in perpetuity. It is made available under aCC-BY-NC-ND 4.0 International license.

\begin{tabular}{|c|c|c|c|c|}
\hline 99 & negative & Sporadic & Malformation of outflow tracts & Australia \\
\hline 100 & negative & Familial & Functional single ventricle & Australia \\
\hline 101 & negative & Sporadic & Malformation of outflow tracts & Australia \\
\hline 102 & negative & Sporadic & Malformation of outflow tracts & Australia \\
\hline 103 & negative & Familial & Malformation of outflow tracts & Australia \\
\hline 104 & negative & Sporadic & Malformation of outflow tracts & Australia \\
\hline 105 & negative & Familial & Functional single ventricle & Australia \\
\hline 106 & negative & Sporadic & Malformation of outflow tracts & Australia \\
\hline 107 & negative & Sporadic & Malformation of outflow tracts & Australia \\
\hline 108 & negative & Familial & Malformation of outflow tracts & Australia \\
\hline 109 & negative & Sporadic & Malformation of outflow tracts & Australia \\
\hline 110 & negative & Familial & Malformation of outflow tracts & Australia \\
\hline 111 & negative & Familial & Heterotaxy & Australia \\
\hline 112 & c.4796G>A p.R1599Q rs569615549 & Sporadic & Malformation of outflow tracts & Australia \\
\hline 113 & negative & Familial & Heterotaxy & Australia \\
\hline 114 & negative & Sporadic & Malformation of outflow tracts & Australia \\
\hline \multirow{2}{*}{115} & c. $307+13 \mathrm{~T}>\mathrm{C}$ & \multirow{2}{*}{ Sporadic } & \multirow{2}{*}{ Malformation of outflow tracts } & \multirow{2}{*}{ Australia } \\
\hline & c. $1278 \mathrm{~A}>\mathrm{G}$ p.E426E rs878855242 & & & \\
\hline 116 & negative & Sporadic & Malformation of outflow tracts & Australia \\
\hline 117 & negative & Sporadic & Malformation of outflow tracts & Australia \\
\hline 118 & negative & Sporadic & Malformation of outflow tracts & Australia \\
\hline 119 & negative & Familial & Malformation of outflow tracts & Australia \\
\hline 120 & negative & Sporadic & Malformation of outflow tracts & Australia \\
\hline 121 & negative & Sporadic & Malformation of outflow tracts & Australia \\
\hline 122 & c. $4886 \mathrm{C}>\mathrm{T}$ p.S1629L & Familial & Malformation of outflow tracts & Australia \\
\hline 123 & negative & Sporadic & Malformation of outflow tracts & Australia \\
\hline 124 & negative & Familial & Malformation of outflow tracts & Australia \\
\hline 125 & negative & Familial & Malformation of outflow tracts & Australia \\
\hline 126 & negative & Sporadic & Malformation of outflow tracts & Australia \\
\hline 127 & negative & Sporadic & Malformation of outflow tracts & Australia \\
\hline 128 & negative & Familial & Malformation of outflow tracts & Australia \\
\hline 129 & negative & Sporadic & Malformation of outflow tracts & Australia \\
\hline
\end{tabular}

$*$, \# and ${ }^{\wedge}$ are 3 pairs of cousins among the familial Italian cohort families 
Supplementary Table 2: Summary of DICER1 Variants and Predictions

\begin{tabular}{|c|c|c|c|c|c|}
\hline Variant & $\mathbf{n}$ & Clinical information & \multicolumn{2}{|c|}{ Prediction } & \multirow{2}{*}{$\begin{array}{c}\text { Minor allele } \\
\text { frequency (MAF) } \\
\text { ExAC(MAF/count) } \\
\end{array}$} \\
\hline Synonymous $\mathbf{n}=5$ & & & SIFT & Polyphen2 & \\
\hline c. $1278 \mathrm{~A}>\mathrm{G}$ p.E426E rs878855242*** & $1 *$ & Malformation of outflow tracts (sporadic) & NA & NA & Not found \\
\hline \multirow{2}{*}{ c.1935G>A p.P645P rs61751177 } & \multirow{2}{*}{4} & 1 Familial & \multirow{2}{*}{ NA } & \multirow{2}{*}{ NA } & \multirow{2}{*}{$0.0095 / 1148$} \\
\hline & & 3 Malformation of outflow tracts (Sporadic) & & & \\
\hline c. $2337 \mathrm{~A}>\mathrm{G}$ p.T779T rs747210633 & 1 & Malformation of outflow tracts (Familial) & $\mathrm{NA}$ & NA & $0.00003 / 4$ \\
\hline c. $2718 \mathrm{C}>\mathrm{T}$ p.R906R rs370692165 & 1 & Sporadic & NA & NA & $0.00008 / 10$ \\
\hline c.5145C $>$ T p.L1715L rs 139500905 & 1 & Malformation of outflow tracts (Sporadic) & NA & NA & $0.0015 / 179$ \\
\hline \multicolumn{6}{|l|}{ Intronic $\mathrm{n}=7$} \\
\hline c. $307+13 \mathrm{~T}>\mathrm{C}$ & $1 *$ & Malformation of outflow tracts (Sporadic) & $\mathrm{NA}$ & NA & novel \\
\hline c.574-5G>A rs368253792 & 1 & Malformation of outflow tracts (Sporadic) & NA & NA & $0.00006 / 7$ \\
\hline c. $1377-4 \mathrm{~T}>\mathrm{G}$ rs 192490028 & 2 & 1 heterotaxy sporadic, 1 Familial & NA & NA & $0.0033 / 401$ \\
\hline c. $2040+29 \mathrm{~T}>\mathrm{C}$ rs 370866625 & $1 * *$ & Malformation of outflow tracts (Familial) & NA & NA & $0.0002 / 19$ \\
\hline $\begin{array}{c}\text { c.3093+149_3093+153delGTTTT } \\
\text { rs575610432 }\end{array}$ & 1 & Malformation of outflow tracts (Sporadic) & NA & NA & $0.0008 / 4 * * *$ \\
\hline c. $5364+18 \mathrm{C}>\mathrm{T}$ rs 777415635 & 1 & Sporadic & NA & NA & $0.00007 / 8$ \\
\hline c. $5527+19 A>G$ rs 765497219 & $1 * *$ & Malformation of outflow tracts (Familial) & NA & NA & $0.000008 / 1$ \\
\hline \multicolumn{6}{|l|}{ Missense $n=6$} \\
\hline c.179C $>$ T p.T60I rs587778228 & 1 & Malformation of outflow tracts (Familial) & Tolerated & Benign & $0.00005 / 6$ \\
\hline c. $278 \mathrm{G}>$ A p.G93E rs776219930 & 1 & Sporadic & Tolerated & $\begin{array}{c}\text { Possibly } \\
\text { damaging }\end{array}$ & $0.00003 / 4$ \\
\hline c.3458G >A p.C1153Y rs762999390 & $1 * *$ & Malformation of outflow tracts (Familial) & Tolerated & Benign & $0.000008 / 1$ \\
\hline c.4796G>A p.R1599Q rs569615549 & 1 & Malformation of outflow tracts (Sporadic) & Tolerated & Benign & $0.0002 / 23$ \\
\hline c. $4886 \mathrm{C}>\mathrm{T}$ p.S $1629 \mathrm{~L}$ & 1 & Malformation of outflow tracts (Familial) & Tolerated & Benign & novel \\
\hline c.5504A>C p.Y1835S rs 747510783 & 1 & Sporadic & Tolerated & $\begin{array}{l}\text { Possibly } \\
\text { damaging }\end{array}$ & $0.00006 / 7$ \\
\hline
\end{tabular}

* individual with 2 variants

** individual with 3 variants

***from 1000 genomes

NA: not applicable 